\title{
PERANAN POPULAR CULTURE DALAM PEMBELAJARAN BAHASA INGGRIS UNTUK MENCIPTAKAN AUTONOMOUS LEARNER DI ABAD 21
}

\author{
Zahra Zikrilla Basri, Vicky Lilla Septiyanti, Fadia Holisah \\ zahrazikrilla98@gmail.com \\ Mahasiswa Fakultas Keguruan dan Ilmu Pendidikan Universitas Ibn Khaldun
}

\begin{abstract}
ABSTRAK
Popular culture itu ada dimana-mana. Anda akan tahu ketika anda membuka internet, mendengarkan musik, menonton televisi, dll. Youtube, musik, drama korea, film animasi jepang (anime), media sosial, dan lain-lain merupakan popular culture yang banyak digandrungi oleh pelajar maupun non-pelajar di Indonesia. Dengan adanya popular culture di abad 21 yang bersifat global ini dapat membantu orang-orang untuk memulai belajar bahasa inggris maupun meningkatkan kemampuan bahasa inggris mereka. Popular culture yang bersifat global di abad 21 ini juga dapat melatih dan menciptakan Autonomous learner yang kompeten dan mandiri. Penelitian ini melibatkan 11 responden yang merupakan mahasiswa jurusan Pendidikan Bahasa Inggris semester 3 dengan beberapa tahapan yaitu mengisi kuesioner, interview, dan observasi. Tanggapan responden cukup beragam, tetapi mereka memiliki kecenderungan yang sama yaitu Youtube sebagai budaya populer yang paling di gandrungi oleh mahasiswa semester 3 jurusan Pendidikan Bahasa Inggris dan cukup efektif dalam meningkatkan pembelajaran bahasa Inggris.
\end{abstract}

Kata Kunci: Popular Culture, Pembelajaran bahasa Inggris, Autonomous learner, Abad 21, Youtube, Social media.

\section{PENDAHULUAN}

Popular culture adalah budaya suatu masyarakat yang mendominasi masyarakat pada suatu titik waktu. Menurut Westerhuis (1995), kata 'populer' awalnya adalah istilah hukum dan politik, dari membawa relevansi pada popularis, yang merupakan bahasa Latin untuk 'milik rakyat'; 'Budaya' bisa didefinisikan sebagai 'kebiasaan, nilai, hukum, teknologi, artefak, dan seni dari waktu atau orang tertentu. Namun, kegunaan popular culture sebagai media unt uk meningkatkan kemampuan berbahasa inggris ini jarang disadari maupun dimaksimalkan, terlebih kepada pelajar umum diluar jurusan bahasa Inggris yang merasa bahwa mereka hanya harus fokus pada bidangnya saja. Seperti yang disebutkan Biggs (1995) bahwa siswa hanya termotivasi untuk belajar hal-hal yang penting dan bermakna bagi mereka. Di dalam kelas bahasa Inggris, pusat belajar ada pada guru yang telah diatur oleh kurikulum yang ditetapkan oleh pemerintah. Mok (1990) menganggap bahwa tipe 'belajar bahasa Inggris dikelas' tidak membantu siswa dalam menghadapi situasi 'kehidupan nyata'. Namun, pemerintah telah membuat pendidikan 
bahasa Inggris seolah sebagai prioritas mengingat bahwa bahasa Inggris merupakan kunci untuk berkomunikasi lintas negara di dunia. Pelajar abad 21 terkenal akan pemikirannya yang kritis, maka pelajar harus dapat mengolah dan memfilter popular culture agar bermanfaat dan membantu meningkatkan English skills dengan mandiri tanpa tutor atau dalam kata lain menjadi autonomous learner. Menurut Ushioda (2011), jika siswa mampu mengambil tanggung jawab untuk, mengelola, dan mengatur pembelajaran mereka sendiri, ini menunjukkan perilaku mereka ditentukan oleh diri mereka sendiri. Dia menyatakan bahwa 'kita ingin siswa kita untuk memenuhi potensi mereka menjadi orang yang mereka inginkan dan melakukan halhal yang mereka hargai dengan cara yang sehat' (ibid: 30). Bertanggung jawab untuk kemajuan pendidikan dirinya sendiri dapat memberdayakan siswa dan mempersiapkan mereka untuk pembelajaran seumur hidup (Egel, 2009). Agar peserta didik menjadi mandiri, sampai dapat terlibat belajar mandiri, kondisi kesiapan psikologis diperlukan, karena otonomi pada dasarnya adalah kapasitas untuk teguh pendirian, kritis refleksi, pengambilan keputusan, dan tindakan independen (Little 1991:4). Terlebih pada era sekarang yang dikenal dengan generasi millenial yang telah terlibat dengan cara hidup, teknologi, dan ide-ide dari negara-negara maju di Barat maupun Asia yang melibatkan penggunaan internet, misalnya, melalui film, musik, youtube, media sosial, dan lain-lain yang menggunakan bahasa Inggris sebagai medium. Bagaimana agar popular culture dapat membantu pelajar dalam meningkatkan kemampuan berbahasa inggrisnya? Seperti yang disarankan oleh Alastair Pennycook yang mengatakan bahwa kita perlu melihat pengajaran bahasa Inggris sebagai ranah yang terletak dalam budaya populer sebanyak yang terletak dalam ranah linguistik terapan (Pennycook 1998 : 162). Anak muda sekarang yang disebut-sebut sebagai generasi millenial tentu sudah lebih terpapar oleh budaya populer dibandingkan dengan kelompok usia yang lain terutama para orangtua dan pendidik yang sering mengkhawatirkan pengaruh dari popular culture kepada kawula muda. Baik minat yang dimiliki pelajar dalam popular culture berbahasa Inggris dan kekhawatiran yang dimiliki pendidik dapat diatasi meningkatkan kesadaran perspektif multikultural dalam kelas bahasa. Konsep yang relatif baru ini secara eksklusif harus di jabarkan pada program pelatihan guru sehingga calon pendidik siap untuk mengelola ruang kelas dengan siswa dari budaya yang berbeda seperti yang diuraikan oleh DeCapua and Wintergerst (2004). Televisi, musik, game, komik, internet termasuk youtube dan media sosial telah membentuk bagian psikologis utama dari kehidupan dan gaya hidup anak muda. White (1985) mengklaim bahwa bagi kebanyakan anak muda, budaya populer berfungsi sebagai alat berharga yang membantu mereka mengatasi kesulitan tugas membangun dan memelihara identitas. Dalam proses tumbuh dewasa, siswa perlu mengidentifikasi dengan sesuatu dan sebagian besar dari mereka memilih budaya populer yang mudah diakses di mana saja dan sangat dapat diterima oleh kaum muda, bertindak sebagai ikatan di antara mereka, juga memberikan makna yang relevan dengan kehidupan mereka. Tujuan dari penelitian ini adalah untuk mengetahui pengaruh budaya populer dalam membantu pelajar atau siswa dalam membantu meningkatkan 
kemampuan bahasa inggris mereka, juga membangun sifat belajar mandiri dan

\section{METODE PENELITIAN}

Penelitian ini kami lakukan dengan mengumpulkan data berdasarkan perspektif responden dalam 3 tahapan diantaranya observasi, mengisi kuesioner, dan semi-structure interview yang merupakan salah satu jenis pengumpulan data yang terdapat dalam metode penelitian campuran. Penelitian ini dilakukan dalam kurun waktu satu minggu yaitu pada tanggal 10-14 dan 17-18 Desember 2018 di lingkungan Universitas Ibn Khaldun.

Metode campuran ini terdiri dari metode penelitian kualitatif dan metode penelitian kuantitatif. Menurut menurut Moleong (2005) penelitian kualitatif merupakan penelitian yang bermaksud utuk memahami fenomena tentang apa yang dialami oleh subjek penelitian. Sugiyono (2012) menyatakan bahwa metode penelitian kualitatif dinamakan sebagai metode baru. Sedangkan menurut Sugiyono (2011) metode penelitian kualitatif adalah metode penelitian yang berlandaskan pada filsafat postpositivisme, digunakan untuk meniliti pada kondisi obyek yang alamiah, dimana peneliti menciptakan autonomous learner di abad 21 yang dikenal denga era millenial.

adalah sebagai instrument kunci, pengambilan sampel sumber data dilakukan secara purposive dan snowball.

Pengertian metode penelitian kuantitatif menurut Kasiram (2008) adalah suatu proses menemukan pengetahuan yang menggunakan data berupa angka sebagai alat menganalisis keterangan mengenai apa yang ingin diketahui. Menurut Sugiyono (2012), metode kuantitatif dinamakan sebagai metode tradisional, karena metode ini sudah cukup lama digunakan sehingga sudah mentradisi sebagai metode untuk penelitian.

Tahap pertama yang kami lakukan adalah observasi, observasi kami lakukan ketika pembelajaran berlangsung selama 5 hari dimulai pada tanggal 10-14 Desember 2018. Tahap ini kami lakukan dengan mengamati kesebelas responden yang telah ditentukan yang berasal dari mahasiswa semester 3 kelas 3A jurusan Pendidikan Bahasa Inggris, Universitas Ibn Khaldun, Bogor ketika pembelajaran speaking, grammar, listening, writing, dan prose.

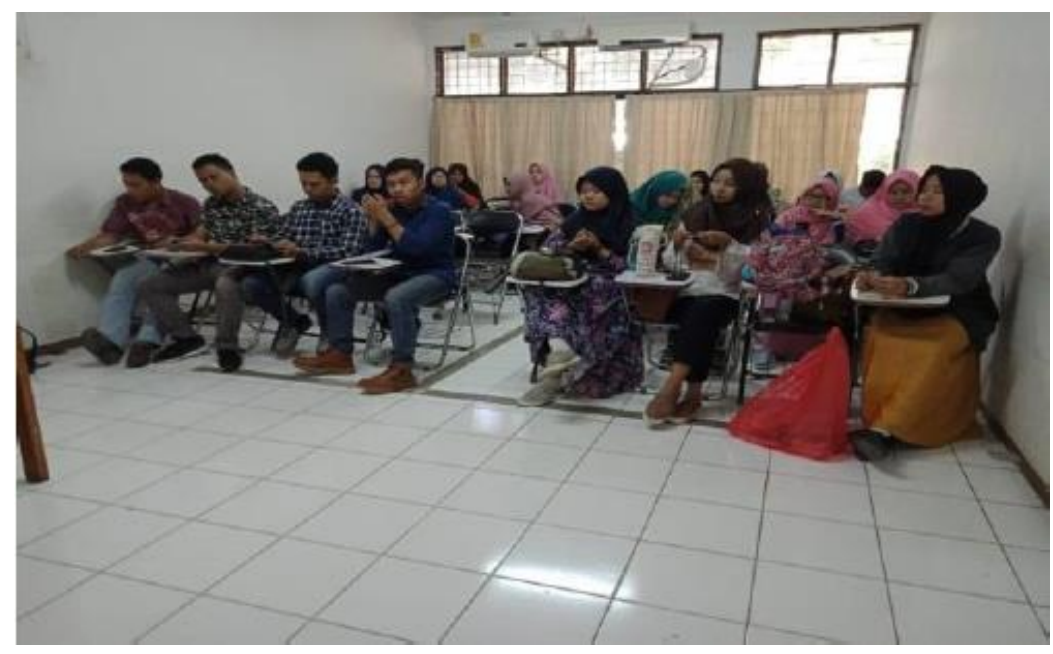


Pada hari Senin, 17 Desember 2018 kami melakukan tahapan selanjutnya yakni tahapan pengisian kuesioner. Kami mengumpulkan kesebelas responden untuk mengisi sebuah kuesioner yang berisi 5 pertanyaan yang berada didalam sebuah link yang telah disediakan.

Tahap terakhir yang kami lakukan adalah tahap interview. Jenis interview yang kami gunakan adalah semi-structured

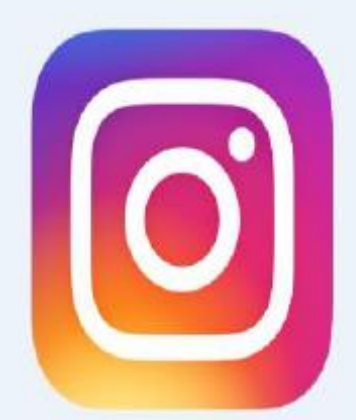

\section{HASIL DAN PEMBAHASAN}

Interview sebagai cara dalam pengumpulan data yang kami lakukan menjadi tahap akhir dalam penelitian ini. Sebelum melakukan interview kami meminta para mahasiswa untuk dapat mengisi beberapa interview. Semi-structured interview adalah jenis interview yang menggunakan beberapa pertanyaan yang telah ditentukan dengan jawaban berupa opini responden (M.Easwaramorty, 2006). Dalam interview ini kami memberikan beberapa pertanyaan yang berkaitan dengan popular culture sebagai media pembelajaran bahasa Inggris dengan jawaban berdasarkan opini mereka setelah menggunakan beberapa media.

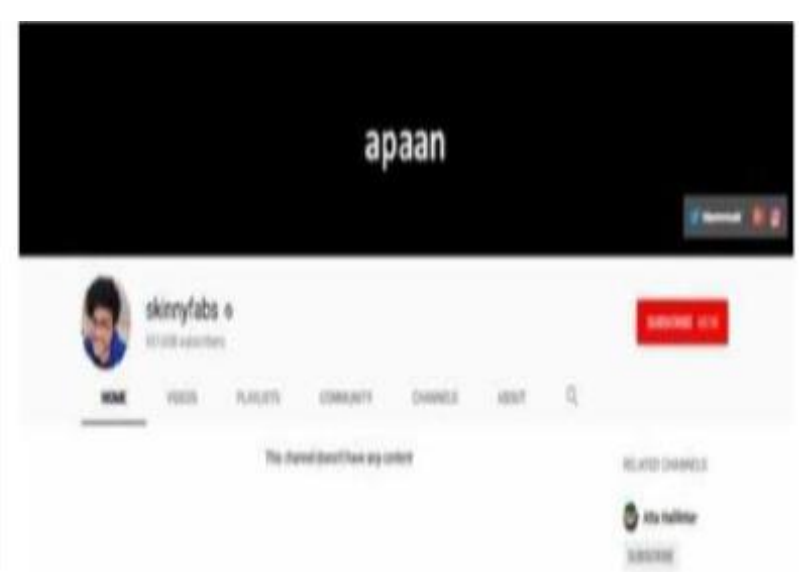

pertanyaan seputar judul yang kami buat. Setelah itu kami mengajukan 5 pertanyaan berkaitan dengan judul yang telah kami pilih beserta alasan mereka tentang itu.

\section{Media yang digunakan}

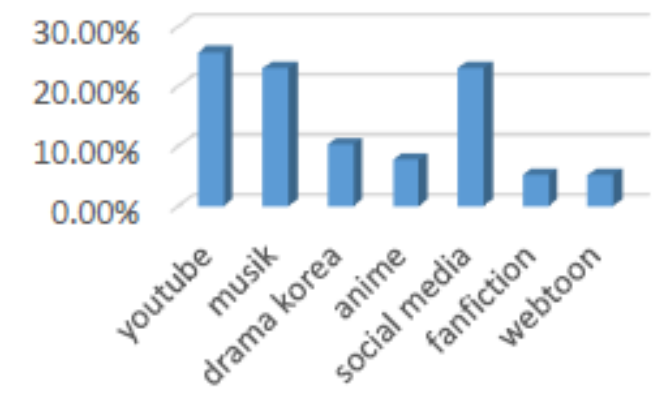

\section{Pernyataan 1}

Dilihat dari hasil diagram presentase 1, menunujukan bahwa hampir seluruh

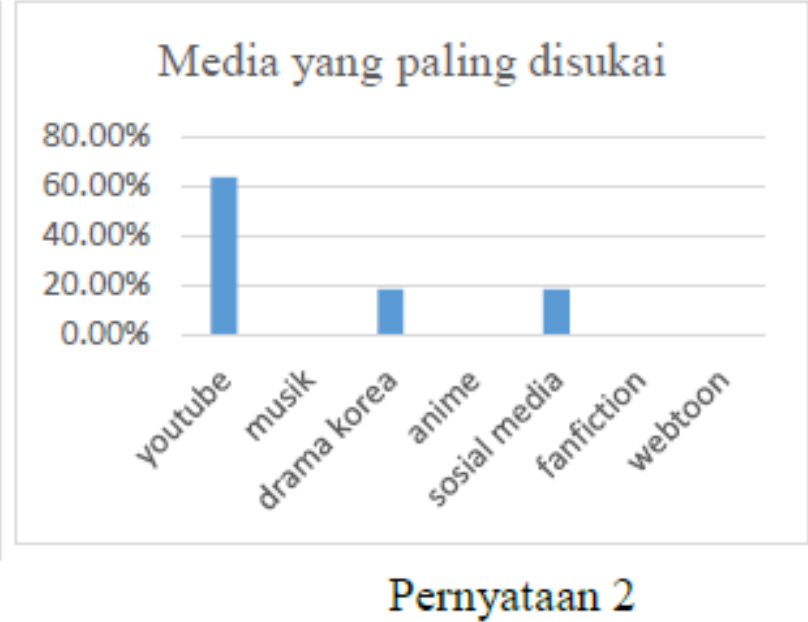

responden yang kami minta untuk mengisi kuesioner memilih youtube sebagai media 
yang paling sering digunakan. Akan tetapi tidak jarang juga yang memillih media sosial sebagai media yang digunakannya diikuti dengan musik, drama korea, anime, fanfiction, dan webtoon.

Dilihat dari hasil diagram presentase 2, menyatakan bahwa $63,64 \%$ diantara responden menggunakan Youtube sebagai media yang paling mereka sukai. Dengan alasan dari hasil interview dari salah satu responden yakni "Ya saya menyukai
Youtube karena di Youtube mencakup semuanya ada anime, drama, musik, dan lain sebagainya, gak punya aplikasi Instagram buat belajar bisa nyari di Youtube. Pokoknya Youtube lebih dari tv." kata responden ke 7. Dari hasil interview tersebut menguatkan hasil observasi maupun hasil dari pengisian kuesioner yang sebelumnya kita amati dan laksanakan.

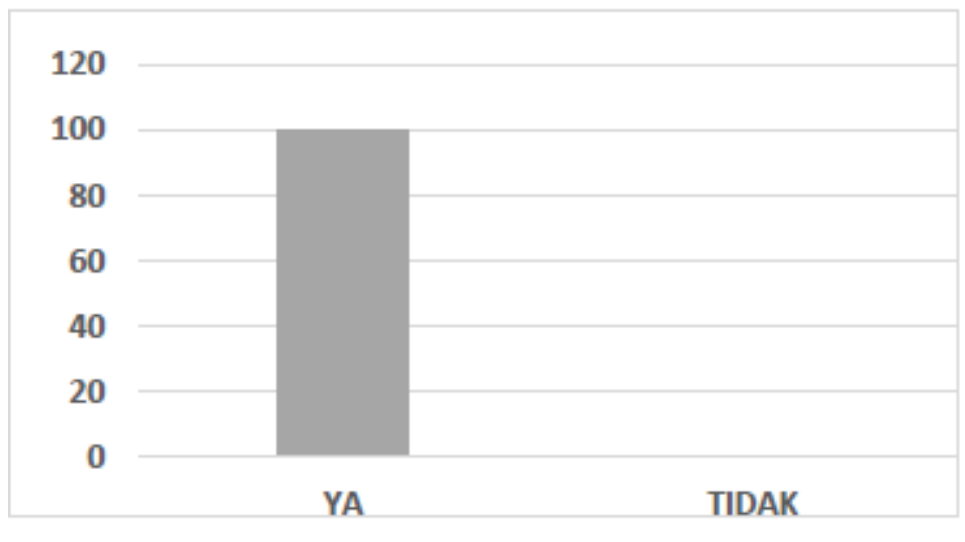

Pernyataan 3

Dilihat dari hasil presentase wawancara 3 menunjukan bahwa 100\% dari kesebelas respoden, media yang mereka gunakan membantu mereka dalam pembelajaran bahasa Inggris. Dilihat dari hasil interview menurut responden ke 4 yang berkata "Menurut saya Youtube bisa membantu saya dalam pembelajaran bahasa Inggris misalnya dalam hal speaking dan pronounciationya." Hal ini dapat menguatkan hasil dari observasi dan pengisian kuesioner yang kami lakukan kepada kesebelas responden tersebut.

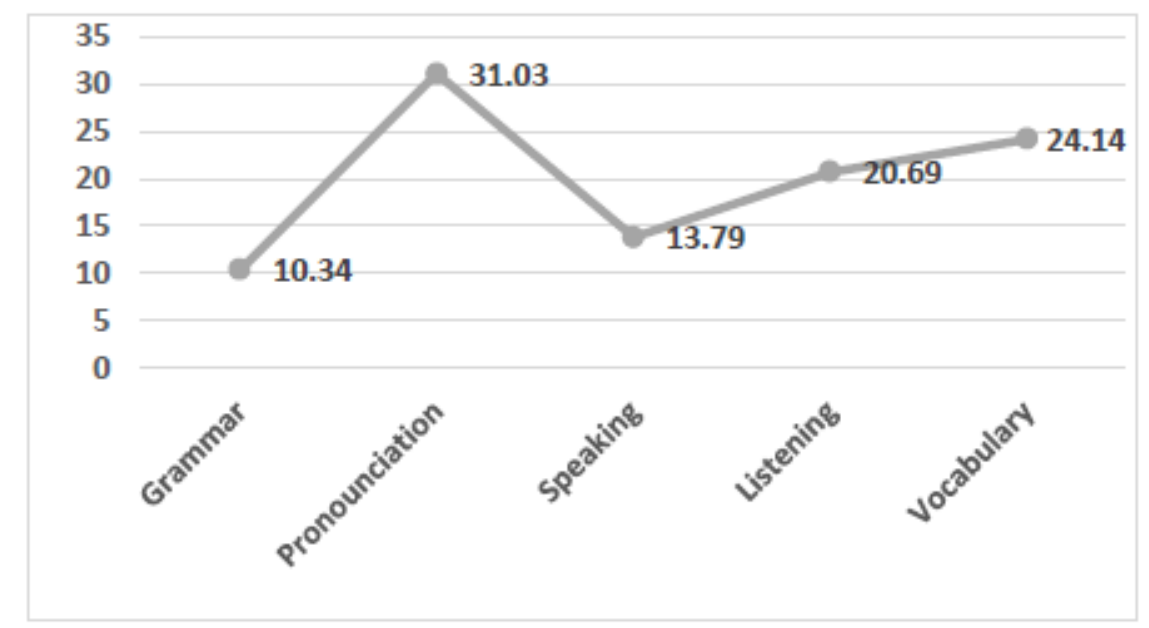

Pernyataan 4 
Dari segi presentase hasil wawancara ke 4 menunujukan bahwa sebagian besar hal yang di dapatkan oleh para responden adalah dalam hal pembelajaran bahasa Inggris adalah pronounciation diikuti oleh listening, speaking, vocabulary, dan grammar. Salah satu responden dari sebelas responden yang kami tanyakan yakni responden ke 2 mengatakan "more about vocab, pronounciation, speaking and listening". Dari hasil interview tersebut sangat menguatkan bukti dari observasi dan pengisian kuesioner yang kita lakukan.

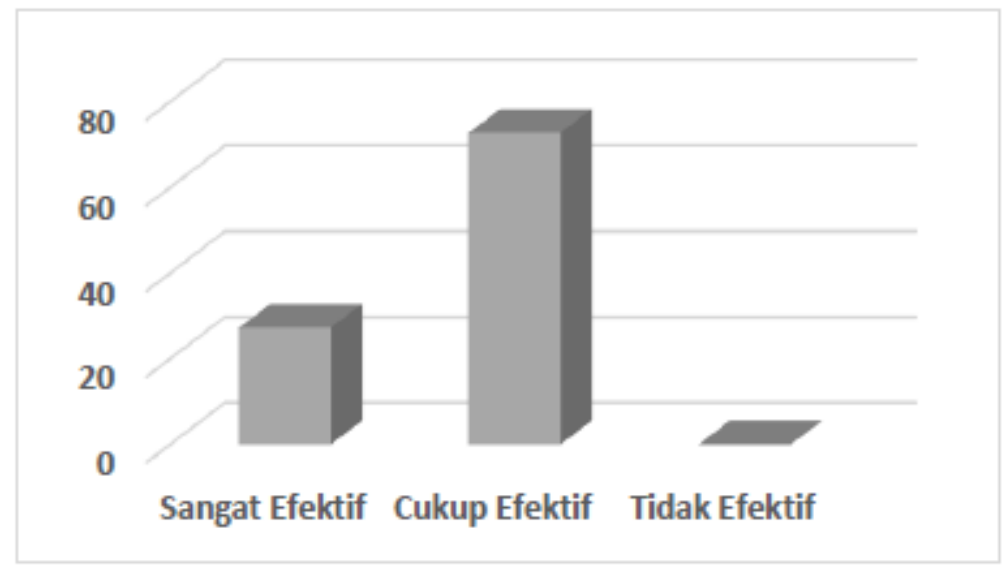

Pernyataan 5

Melihat hasil wawancara terakhir menyatakan bahwa belajar bahasa Inggris menggunakan popular culture cukup efektif. Hal ini cukup membantu para responden dalam pembelajaran bahasa

\section{KESIMPULAN}

Budaya populer dapat menjadi salah satu aspek yang sangat berpengaruh terhadap perkembangan kemampuan bahasa inggris pelajar di abad 21 ini, terlebih sekarang jendela ilmu pengetahuan sudah terbuka luas dan segala macam informasi bebas dan mudah diakses sehingga pelajar dapat belajar dan mengembangkan kemampuan bahasa inggrisnya dimanapun dan kapanpun juga menjadikan pelajar lebih mandiri dalam memperoleh ilmu. Oleh karena itu pentingnya mengolah dan memfilter budaya populer sehingga bukan hanya sebagai gaya hidup namun juga dapat
Inggris disamping pembelajaran didalam kelas. Akan tetapi ada beberapa diantara mereka mengatakan bahwa pembelajaran melalui popular culture sangat efektif.

membantu meningkatkan aspek kognitif pelajar diantaranya pengetahuan, vocabulary, grammar, listening, speaking, pronounciation, dll. Hasil studi mengungkapkan bahwa budaya populer yang paling banyak membantu dalam meningkatkan kemampuan bahasa inggris pelajar adalah Youtube. Dengan melalui video di youtube, konten di media sosial, musik, subtitle film, dll, pelajar dapat menambah pengetahuan kosakata dan meningkatkan kemampuan aspek-aspek bahasa inggris dengan efektif dan mandiri sehingga dapat menciptakan autonomous 
learner yang kompeten dan mampu bersaing global.

\section{DAFTAR PUSTAKA}

Biggs, J.1995. 'Motivating learning' in J. Biggs and D. Watkins (eds.). Classroom Learning. Singapore: Prentice Hall.

DeCapua, A. and A. C. Wintergerst. 2004. Crossing Cultures in the Language Classroom. Ann Arbor, MI: The University of Michigan Press.

Eastwaramorthy, M. 2006. Interviewing for Research.

Egel I. 2009. Learner autonomy in the language classroom: from teacher dependency to learner independency. Procedia - Social and Behavioral Sciences 1: 2023-26.

Kasiram, Moh. 2008. Metodologi Penelitian. Malang: UIN-Malang Pers.

Little, D. 1991.Learner Autonomy: Definitions, Issues and Problems. Dublin: Authentik.

Mok, A. H. M.1990. Using newspaper materials in the English curriculum: Guidelines and practical examples. Faculty of Education, Hong Kong University.
Moleong, j, Lexy. 2005. Metodologi Penelitian Kualitatif. Bandung: Remaja Rosdakarya.

Pennycook, A.1998. English and the Discourse of Colonialism. London: Routledge.

Sugiyono. 2012. Metode Penelitian Kuantitatif, kualitatif dan $\mathrm{R} \& \mathrm{D}$. Bandung: Alfabeta.

Sugiyono. 2010. Metode Penelitian Pendidikan. Bandung: Penerbit Alfabet.

Ushioda, E. 2011.'Why autonomy? Insights from motivation theory and research'. Innovation in Language Learning and Teaching 5/2: 221-32.

Westerhuis, D.1995. Society and Culture. Pascal Press. Sydney: Australia.

White, A.1985. 'Meaning and effects of listening to popular music: implications for counselling'.Journal of Counselling \& Development 64/1: 65-9. 